\title{
EFFECTS OF IMPROVED PRACTICAL SKILL ON COLLEGES OF EDUCATION (TECHNICAL) STUDENTS IN UPHOLSTERY AND MACHINE WOODWORKING FOR NATIONAL DEVELOPMENT IN ETHNO-BASED EDUCATION
}

\author{
Onaga, Paul Okwudilichukwu \\ Enugu State College of Education (Technical), Enugu \\ Abakaliki Road P. M. B. 01793 Enugu
}

\begin{abstract}
This study on effects of improved practical skills on Colleges of Education (Technical) students tends to determine the implication for the use of improved skills over conventional skills in teaching students practical skills. Improvement of the value of graduates for better employability is needed perceiving the fact that technology and products are changing tremendously. Two research questions guided the study. The study adopted a Quasi-experimental design. Data were collected by observational method to a population of 21 woodwork students. A task assessment schedule was developed as an instrument by the researcher and validated by three experts. Table of specification was used to determine the reliability of the instrument. Data were analyzed using mean scores. Mean scores of the students were determined to answer the two research questions. The result of the study indicates that improved practical means of teaching has high effect on the students. Among the suggestions were that improving practical teaching should be prioritized in the schools, especially in TVET related schools.
\end{abstract}

Keywords: Practical Skills, Ethno-based, Development, Machine Woodworking, Upholstery

\section{INTRODUCTION}

\subsection{Background to the Study}

Most developing nations are struggling to meet up with the trend of the global moving train. Countries like India, North Korea and et cetera are joining the trend but Nigeria is yet to join. This may be related to the adaptation of these countries to Technical Vocational Education and Training (TVET). To compete globally, nations are queuing up and aligning to the new economic improvement for their national development. There are a lot of indices under check for qualification to become a developed country and one of such is self employment of citizens which brings about small business enterprises. The purpose of TVET is to make people self-employable and to be a vehicle of transition for individuals to the world of work (Hollander and Mar, 2009). Consequently, in the perfect case, TVET leads to self-employment and income-generation which is expected to contribute to the general well being of the individuals and communities. United Nations (UN) has the agenda of developing the poorer nations as well as trying to spur them into the struggle to meet up with the developed countries. It is believed that increasing the value of TVET in the poorer nations will increase industrialization and bridge the gap between developed and developing nations. Okolo (2008) noted that technical education courses which are part of TVET are included not only for diagnostic value but for purely educational value. 
There is no gainsaying the fact that TVET is often considered as a mechanism for poverty alleviation. International development goals are mostly achieved through the contribution of TVET. Woodwork technology is basically one of the areas of interest in TVET that helps nations become developed by increasing the Gross Domestic Product per capita. Nevertheless, value system has changed the school contents, methods, and approaches to teachinglearning. Scholars like Omar, Khuan, Kamaruzaman, Awang, and Jamal (2011) maintained that introduction of technology as a novelty in the educational sector has transformed the trend and profile of students; created new needs in knowledge and technology areas; and modified the roles and function of schools, making them more challenging than ever before. There is a continuous rapid development in technology and value for appliances which have motivated the interest in the need to update teachers' competencies to make them relevant and increase value in education. This reality needs to be accepted by education stakeholders as such practical train intensification is eminent. The quality of teachers is what they can give while teaching. Hence the value and standard of education in Nigeria depends on the quality of the teachers (Nwabuisi, 2008) as such an urgent need for proper teachers' capacity building especially in areas of woodwork like machine woodworking, upholstery, et cetera. The Woodwork Technology education students who are would be teachers need to be well equipped to fill the needed gap in practical classes like machine woodworking and upholstery.

Machine woodworking is that area of woodwork where the students' skills and knowledge in the use of wood working machines for the preparation of timber components for joinery and furniture construction are increased (Onaga, 2015). The students learn working principles, functions, simple routing maintenance and methods of operating woodwork machines. FGN (2001) in NABTEB syllabus stated that Upholstery making is the work of providing furniture, especially seats, with padding, springs, webbing, and fabrics or leather covers. The term is applied to domestic and office furniture in addition to automobiles, airplanes and boats.

Unfortunately, paucity of practical classes in the woodwork related subjects in Colleges of Education (Technical) increases the number of unemployed youths within the society and have made the nation unable to meet up with the emerging challenges of the $21^{\text {st }}$ century because the quality of graduates is not standard when compared to developed countries. FGN (2013) maintained that no nation could grow above the quality of its teachers. As a matter of fact, most woodwork students of Colleges of Education (Technical) are ill prepared for meeting the challenges of modern times as some of the wood products they produce lack aesthetics, durability and strength to match the architecture of today. On the other hand they may lack the ability to enter the classrooms and develop the younger generation. Consequently, Ogwo and Oranu (2006) noted that training offered in school system is not enough to guarantee expertise in most occupational areas in recent time thereby suggesting increase in practical classes for woodwork technology students in Colleges of Education (Technical) to increase skill base. When the would-be teachers' knowledge and skill base increases, transfer of knowledge becomes eminent, therefore students learn and national development improves. Thus the study to determines the practical skills required by Colleges of Education (Technical) students in machine woodworking and upholstery for national development.

\subsection{Purpose of the Study}

The purpose of the study is to determine the Practical skills required by Colleges of Education (Technical) students in upholstery and machine woodworking trade for national development. Specifically the following research questions were formulated to guide the study:

1. What is the effect of improved practical skills on Colleges of Education (Technical) students in machine woodworking for national development?

2. What is the effect of improved practical skills on Colleges of Education (Technical) students in upholstery making for national development?

\section{METHODOLOGY}

A quasi experimental design was adopted for the study. Two schools with the same National Commission for Colleges of Education (NCCE) minimum standard were used for the study. While practical classes were improved in one, the conventional approach was used in the other. The population of the study is 21 woodwork students of Colleges of Education (Technical) in South East Nigeria which also served as the sample for the study. The researcher taught the two groups the skills but increased the time of teaching one of the groups. After the teaching period the students were tested with same tests known as task assessment 
schedule and decisions were taken based on the performance of the groups. Three experts validated the tests used as the instrument. Table of specification was used to determine the reliability of the instrument. Mean scores of the students were determined. The test has 20 tasks and was given 5\% for each task correctly performed to make up $100 \%$. The differences between the mean scores of the two groups show whether the effect is positive or negative.

\subsection{Research Question 1}

What is the effect of improved practical skills on Colleges of Education (Technical) students in machine woodworking for national development?

Table 1

Scores on the effect of improved practical skills on Colleges of Education (Technical) students on Upholstery difference between the two groups is 12.5. this shows that the experimental group is better with an average of 12.5 marks. This means that improving the practical skill will definitely increase the students' learning standard.

\subsection{Research Question 2}

What is the effect of improved practical skills on Colleges of Education (Technical) students in machine woodworking for national development?

Table 2

Scores on the effect of improved practical skills on Colleges of Education (Technical) students on Machine Woodworking.

$$
N=21
$$

\section{\begin{tabular}{|l|l|l|l|l|}
\hline S/N & Tasks to be performed & Contr & Expe & Differ \\
\hline
\end{tabular}}

ol rime ence

$N=21$

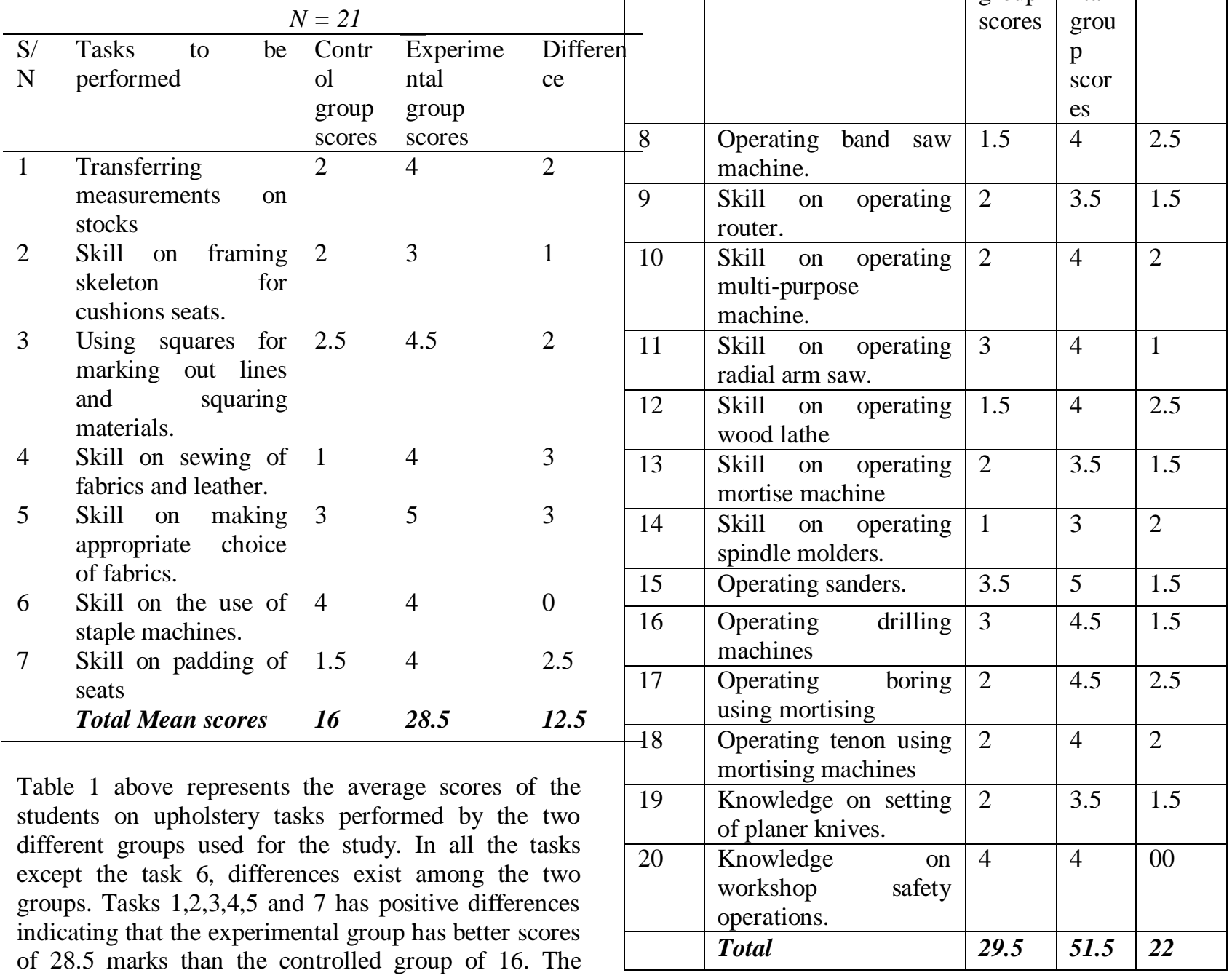


Table 2 above represents the average scores of the students on machine woodworking tasks performed by the two different groups used for the study. The average scores the experimental group of 51.5 against that of the controlled group of 29.5 shows that the improved practical skills has high effect. This is evident in the individual mean scores of the tasks used for the study.

\subsection{Discussion of findings}

The result of the study as shown in Tables 1 and 2 indicates that improved practical enhances learning over the conventional method. This means that there is high effect of improved practical on upholstery and machine woodwork. The mean scores of the respondents show a difference of 12.5 and 22 for upholstery and machine woodworking respectively. The result of the study is in agreement with the findings of Kibirige, Maake, and Mavhunga (2014) whose result established that practical work improves students understanding and increases interest in learning. Also it agrees with Amponsah, AddoMensah, Anokye, Babah, and Etsiwah, (2019) who asserts that practical work and motivation of students increases students desire to study STEM related subject.

\subsection{Implication for Ethno-Based}

It is the belief of Okwaria and Upu (2017) that ethnobased education enhances the achievement of students. Because ethno-based instruction has to do with the culture of teaching and impacting technological knowledge and skills for sustainable national development, the result of the study agree that it is an effective means of teaching. The ethno-education may refer to the materials, ideas, beliefs and technology in a given society or environment, derived from the past and present cultural practice and traditions of students. In words of Ugwuanyi (2015) it may evolve from myth, supernatural, and mystical realities as well as ongoing acculturation in the environment. Ethnoeducation is the knowledge that is of indigenous to particular groups, language, beliefs, technologies and cultures of a people. In other words ethno-education is the study of humans' interaction with the natural environment and the construction of realities that link culture with advance scientific knowledge. The use of improved practical means for teaching upholstery and machine woodwork relating to the cultural value of a people is an ethno-based education and need to be encouraged for national development. For instance, the traditional production of musical instruments and wooden home appliances like wooden gong, Ikoro, traditional institution stools kings, and others in Igboland may be encouraged. The use of the new and improved technology and practical values to produce these materials will change the mindset of many youths to understand that some of those locally made material as mentioned above and more are not fetish as ascribed. This will improve the ethno-based education and bring studies back to the cultural value especially in Africa in emulation to the likes of the Asian Tigers.

\section{CONCLUSION AND RECOMMENDATION}

Based on the result of the study it is deduced that improving practical lessons will definitely enhance the students' interest in learning woodwork technology practices. This tends to support the saying that students learn more and faster when taught with concrete objects than in the use of abstract means of teaching where students do not see anything relating to what they intend to learn. It is therefore recommended that

1. Improving practical teaching should be prioritized in the schools, especially in TVET related schools.

2. Practical lesson time must be increased to give more room for the students to practice the given tasks instead of making the theoretical.

3. Also cultural values of the society must be prioritized and developed to match the technology moving trend.

\section{REFERENCES}

[1] Hollander, A., \& Mar, N. Y. (2009). Towards achieving TVET for all: the role of the unescounevoc international centre for technical and vocational education and training. In International handbook of education for the changing world of work (pp. 41-57). Springer, Dordrecht.

[2] Okolo O. M. (2008). Principle and methods in vocational and technical education; University Trust Publishers, Nsukka. Pp 43-52

[3] Omar A. K., Khuan, W. B., Kamaruzaman J., Awang, M., Jamal, N. Y. (2011). Teacher Capacity Building in Teaching and Learning: The Changing Role of School Leadership: (9),1. http://www.adacemicleadership.org 22/09/2012. 
[4] Nwabuisi, E. M. (2008). Education for what? An inaugural lecture of the University of Nigeria, Nsukka delivered on April 15 ${ }^{\text {th }}$ 2008. Pp. 10-14

[5] Onaga, P. O. (2015). Capacity building needs of woodwork teachers in technical colleges and industrial woodworkers in Enugu state, Nigeria. Unpublished Master Thesis. University of Nigeria, Nsukka.

[6] Federal Republic of Nigeria (2001). NABTEB Syllabus (Revised Edition). Lagos: NERDC press.

[7] Federal Republic of Nigeria (2013). National Policy on Education (Revised Edition). Lagos: NERDC press.

[8] Ogwo, B. A. and Oranu, R. N. (2006). Methodology in Formal and Non-Formal in Vocational Education. Ijejas Printers and Publishers Company Enugu. Pp. 116-143

[9] Kibirige, I., Maake, M. R. and Mavhunga F. (2014). Effect of Practical Work on Grade 10 Learners' Performance in Science in Mankweng Circuit, South Africa. Mediterranean Journal of Social Sciences 5(23)

[10] Amponsah, I., Addo-Mensah, D. Anokye, M., Babah, R. and Etsiwah, I. (2019). The Effect of Practical Work and Motivation on Students' Desire to Study STEM Subjects Conference: 11th International Conference on Education and New Learning Technologies, At Palma de Mallorca, Spain, Volume: Pgs: 990-999

[11] Okwaria, O. K., \& Upu, F. T. (2017). Effects of Ethno-Science Instructional Approach on Students' Achievement and Interest in Upper Basic Science and Technology in Benue State, Nigeria. International Journal of Scientific Research in Education, 10(1), 69-78. Retrieved [4/11/2019] from http://www.ijsre.com.

[12] Ugwuanyi, E. C. (2015). Effects of an ethnoscience based instructional model on students' academic achievement and interest in the senior secondary school biology. Unpublished master thesis: University of Nigeria Nsukka. 